San Jose State University

From the SelectedWorks of Marjorie R. Freedman

January, 2011

\title{
Freshman Orientation Sessions Can Teach Incoming Students About Healthful Lifestyles
}

Marjorie R. Freedman, San Jose State University

Jennifer Waldrop, San Jose State University 


\section{Freshman Orientation Sessions Can Teach Incoming Students About Healthful Lifestyles}

Journal of Nutrition Education and Behavior

Authors

Marjorie R. Freedman and Jennifer Waldrop

\section{INTRODUCTION}

Currently, $32 \%$ of college students are overweight or obese (body mass index [BMI] $\geq$ 25) (1). This is likely due to many adolescents entering college with an elevated BMI (2). Further, the transition from high school to college is associated with weight gain (3). On their own for the first time, freshmen have greater independence in all aspects of their lives. Increased independence, in turn, often results in changes in types of foods and beverages consumed, and in overall eating and exercise patterns - changes that often affect weight gain (4). Although the popular media continues to perpetuate the "Freshman 15" myth, a recent meta-analysis reported freshmen gain, on average, $<4 \mathrm{lbs}(5)$. This relatively small weight gain means perpetuation of the "Freshman 15" myth might lead to unhealthy dietary attitudes and behaviors (such as extreme dieting and exercise) among incoming students fearful of gaining weight $(5,6)$. Thus, nutrition education on a college campus can fill an important role teaching about adoption of healthy behaviors to prevent weight gain while discouraging extreme weight loss efforts.

Freshman orientation sessions, covering various aspects of campus life, are often conducted prior to the school year. From the published information regarding these orientation sessions, however, they do not appear to include information that could dispel the "Freshman 15" myth, and provide practical solutions for navigating the college food environment for this student group. This paper is the first to describe a nutrition workshop specifically aimed at college freshmen while attending summer orientation programs at a large metropolitan public university. The goals of this workshop were to orient incoming students to the college food environment, to dispel myths about "The Freshman 15", and to provide incoming students with lifestyle choices they could employ to maintain a healthy body weight and prevent disordered eating.

\section{PROGRAM DESCRIPTION AND IMPLEMENTATION}

This university requires all incoming freshmen and their parents to attend a 1.5-day orientation program, in which they are introduced to campus resources, course requirements and student life. Students enroll in 2 different 30-minute information sessions of their choice, covering various topics to help acclimate them to campus life. In 2007, the campus dietitian and a nutrition professor developed a curriculum for, and presented (with help from nutrition graduate students), a nutrition information session known as "Freshman 15 Jeopardy". The session title was purposely chosen to attract a higher risk audience that might be concerned about freshman weight gain. Utilizing a traditional Jeopardy format adapted for PowerPoint, the game, developed using Social Cognitive Theory (SCT) constructs (7), was designed to facilitate interaction among students, parents and session leaders. It was developed to build the skills (i.e., 
label reading, discerning appropriate portion sizes, estimation of caloric needs) that students need to be healthy in an all-you-can-eat environment, and to increase students' self-efficacy and outcome expectations for adopting healthful lifestyle behaviors during the transition to college. In accordance with SCT, the game examined personal attitudes, and environmental and behavioral cues that incoming freshmen could address in order to maintain a healthy weight and avoid high-risk dieting behaviors. Further, the activity sought to increase incoming students' intention to make more healthful selections, and participate in physical activities on campus.

The Jeopardy game included 5 categories, each containing 5 questions regarding general nutrition knowledge ("Portion Size," "Fruits and Veggies," "Know Your Food Label”), or information specific to the university ("The Dining Commons," "Staying Healthy on Campus") (Table 1). As with the traditional Jeopardy game, increasingly challenging "answers," to which the workshop participants provided corresponding "questions," were awarded more points. Session leaders read the Jeopardy "answers" and allowed participants to guess at possible "questions." When the correct "question" was provided, the session leaders expanded upon the specific information using various props (e.g. food models, cups illustrating portion sizes, healthful snack items). Leaders further provided students methods to make healthful food choices and incorporate physical activity into their lifestyles, and ways to utilize social supports. The Jeopardy game also introduced students to the campus and its amenities, such as dining and recreational facilities, and important resources including the counseling center and student health center (where the campus dietitian works). Students were encouraged to ask additional questions to increase their understanding and utilization of campus resources. At the end of the session, the parent/student team with the most points won a small prize.

Table 1. Sample "Freshman 15 Jeopardy" Questions and Answers

\begin{tabular}{|l|l|l|}
\hline \multicolumn{1}{|c|}{ Category } & \multicolumn{1}{|c|}{ "Answer" } & \multicolumn{1}{c|}{ Corresponding "Question" } \\
\hline Portion Size & $\begin{array}{l}\text { The item with more calories: Orange } \\
\text { Dream Machine (Jamba Juice, power } \\
\text { size) or king size French fries. }\end{array}$ & $\begin{array}{l}\text { What is Orange Dream } \\
\text { Machine, with 690 calories? }\end{array}$ \\
\hline Fruits and Veggies & $\begin{array}{l}\text { The portion of your plate that should be } \\
\text { covered by fruits and vegetables. }\end{array}$ & What is one-half? \\
\hline $\begin{array}{l}\text { Know Your Food } \\
\text { Label }\end{array}$ & $\begin{array}{l}\text { The amount of fat (in grams) in a low-fat } \\
\text { food. }\end{array}$ & What is $\leq 3$ grams? \\
\hline $\begin{array}{l}\text { The Dining } \\
\text { Commons }\end{array}$ & $\begin{array}{l}\text { The number of minutes to wait before } \\
\text { getting a second helping. }\end{array}$ & What is 20 minutes? \\
\hline $\begin{array}{l}\text { Staying Healthy on } \\
\text { Campus }\end{array}$ & $\begin{array}{l}\text { A place on campus where you can learn } \\
\text { to eat healthier. }\end{array}$ & $\begin{array}{l}\text { Where is the student health } \\
\text { center (home to the campus } \\
\text { dietitian)? }\end{array}$ \\
\hline
\end{tabular}

\section{EVALUATION AND FUTURE USES}

This workshop has not been formally evaluated to determine changes in student knowledge or behavior, primarily because of time constraints at orientation sessions to assess knowledge change, and lack of follow-up during the semester to assess behavioral change. However, over 1,200 students and parents have attended the workshop over a 3-year period. Program evaluations indicated an overall rating of 4.4 (where $1=$ poor, $2=$ fair, $3=$ average, $4=$ good and $5=$ excellent). Anecdotally, students and parents remarked how much they learned, and expressed appreciation for the exposure to practical nutrition and physical activity 
information. Although one 30-minute session is clearly not sufficient to create lasting behavioral changes, these workshops demonstrated to incoming students and parents that the university is concerned about student health. In addition, messages conveyed are reinforced throughout the school year through campus health initiatives. In sum, this workshop presents a viable option for introducing incoming freshmen to healthier meal planning selections and physical activity options on campus.

Others looking to implement this type of workshop could easily modify Jeopardy "answers" and "questions" to highlight their own campus-specific healthy food and lifestyle options. In addition, this Jeopardy game could be "played" in other on-campus venues, such as residence hall meetings and seminars, and is not limited to freshmen use. Any student who seeks information on a healthier campus lifestyle would likely benefit from playing this game.

\section{NOTES}

The San José State University Institutional Research Board categorized this research as exempt. The authors would like to thank Leslie Wiley for help in manuscript preparation, and the nutrition graduate students who helped run the orientation sessions.

\section{REFERENCES}

1. The American College Health Association. American College Health Association-National College Health Assessment Spring 2008 Reference Group Data Report (Abridged). J Am Coll Health. 2009;57:477-488.

2. Ogden CL, Carroll MD, Flegal KM. High body mass index for age among US children and adolescents, 2003-2006. JAMA. 2008;299:2401-2405.

3. Crombie AP, Ilich JZ, Dutton JR, Panton L, Abood D. The freshman weight gain phenomenon revisited. Nutr Rev. 2009;67:83-94.

4. Cluskey M, Grobe D. College weight gain and behavior transitions: male and female differences. J Am Diet Assoc. 2009;109:325-329.

5. Vella-Zarb, RA, Elgar FJ. The 'Freshman 5': A meta-analysis of weight gain in the freshman year of college. J Am Coll Health 2009;58:161-166.

6. Graham MA, Jones AL. Freshman 15: valid theory or harmful myth? J Am Coll Health. 2002;50:171-173.

7. Bandura A. Social Foundations of Thought and Action: A Social Cognitive Theory. Englewood Cliffs, NJ: Prentice Hall; 1986. 